\title{
11. MESOZOIC VARIEGATED AND RED SEDIMENTS OF THE WESTERN NORTH ATLANTIC, DSDP LEGS 43 AND 44
}

\author{
Ivar O. Murdmaa, P. P. Shirshov Institute of Oceanology, USSR Academy of Sciences, Moscow, USSR
}

\section{INTRODUCTION}

The western North Atlantic section consists mainly of gray, black, and bluish white hemipelagic sediments which were deposited and subjected to early diagenesis under reducing conditions. Authigenic (diagenetic) minerals in these sediments with bivalent iron manganese include pyrite, siderite, glauconite, rhodochrosite, and manganic siderite. Authigenic iron and manganese oxides are virtually absent in the reduced layers. In contrast to the reduced sediments, several brown, red, and variegated layers occur. They indicate the presence of oxidized iron and manganese and obviously represent oxidizing conditions of sedimentation and early diagenesis.

Two distinct intervals of this oxidized sediment were described from the western North Atlantic on the basis of DSDP Leg 11 drilling: (1) Upper Jurassic red and variegated limestone, marly limestone, calcareous claystone; (2) Upper Cretaceous to Paleocene (?) variegated claystones (Hollister, Ewing, et al., 1972). Both intervals were drilled at Site 391 of Leg 44 (this volume). The Upper Cretaceous sequence was also cored at Sites 382, 385, 386, and 387 of Leg 43 (Tucholke, Vogt, et al., in press). In addition, Cretaceous (Aptian to Albian) variegated and brown chalks were drilled at Site 390 (Leg 44). Analogies may be drawn with the Maestrichtian nannofossil chalk in Hole 384 (Leg 43). Intervals of similar red and variegated sediments have also been drilled in the eastern Atlantic continental margins during several DSDP legs $(14,40,41)$.

We conducted geochemical and mineralogical investigations on several tens of samples from Legs 43 and 44 and also utilized published data by Lancelot et al. (1972), and X-ray determinations by Zemmels et al. (1972), Koch and Rothe (in press), and Flood (this volume). On the basis of these data I discuss lithologic, geochemical, and mineralogic aspects of these peculiar variegated and red sediments in order to compare the sediments from different locations.

\section{LITHOLOGY, STRATIGRAPHY, AND ACCUMULATION RATES}

The Upper Jurassic red limestone and marl were first drilled during Leg 11 at Sites 99, 100, and 105 (Lancelot et al., 1972). They directly overlie basaltic basement at Hole 105. Hole 391C, in the Blake-Bahama Basin, was terminated in similar sediments, but drilling did not penetrate to the base of the unit. Seismic data show that 250 meters to 360 meters of sediments underlie the red limestone and marl sequence at Site 391, which must comprise at least one more lithologic unit (Sheridan et al., this volume). Thus the red sediments are not necessarily related to contact with basalt nor are they a basal "metalliferous" layer.
The upper boundary of the red limestone and marl of Unit 5 at Site 391 (see Site 391 Report, this volume) is drawn arbitrarily according to a color change from red to gray. The transition is gradational; no sharp changes were noted in either composition or texture (see Lithologic Summary, Site 391 Report, this volume). The red marl and limestone are Oxfordian-Kimmeridgian to lower Tithonian, but age determinations on the basis of microfossils are not sufficiently refined to allow detailed calculations of accumulation rates. We do know, however, that the rate was much lower than that of the overlying gray limestone.

At Site 100 the Oxfordian to Kimmeridgian red limestone and marl overlie Callovian or Oxfordian greenish gray limestone, whereas at Site 105 the red limestone is directly in contact with basalt. At Site 105, upper Tithonian to Neocomian white to light gray limestones with dark gray, marly interbeds overlie the red limestone. The upper boundary of the red Tithonian unit seems to be gradational; pink, brownish gray, and greenish gray interbeds along with numerous clasts of the different colors occur between the red and gray units. At Site 105 the red unit accumulated at an average rate of about $6 \mathrm{~m} / \mathrm{m}$.y.; this is less than that of the overlying greenish gray unit (Hollister, Ewing, et al., 1972). However, age determinations are not precise enough to allow calculation of the actual accumulation rates.

Upper Cretaceous variegated claystone is present on top of Albian to Cenomanian organic-carbon-rich black and greenish gray claystone in the North American basin at Sites 101 and 105 of Leg 11 (Hollister, Ewing, et al., 1972) and 386, 387 of Leg 43 (Tucholke, Vogt, et al., in press). It occurs on top of the Upper Cretaceous volcaniclastic sequence of the New England Seamounts at Sites 382 and 385 (Tucholke, Vogt, et al., in press). At Site 391, in the BlakeBahama Basin, an interval of red and variegated sediments is present on top of the Aptian to Cenomanian black and greenish gray claystones (Hole 391A, Core 29; Hole 391C, Cores 5, 6). A minor upper Aptian to lower Albian variegated layer is associated with a thin limestone interbed within the black clay unit in Hole 391C, Core 10. In the eastern North Atlantic variegated claystone overlies black shale on the western side of the Canary basin (Sites 137, 138; Hayes, Pimm, et al., 1972) and in the Cape Verde Basin (Site 367; Lancelot, Seibold, et al., 1977).

The variegated sediments are overlain by hemipelagic sediments of a totally different lithology and age. The overlying sediments include (1) upper Tertiary (Miocene to Pliocene) hemipelagic clay and silty clay at Sites 105, 106, 382; (2) Maestrichtian marly nannofossil ooze, chalk, and calcareous clay at Sites 385, 387; (3) lower Eocene silicified claystone and calcareous claystone at Site 386; (4) lower Miocene intraclastic chalk and mudstone (gravity flow de- 
posits) at Site 391. Thus, a marked change in lithology between the variegated sequence and overlying units was noted in all the studied sections. The overlying units are distinct from the variegated sediments and are commonly separated from them by a hiatus.

The variegated and red sediments are virtually devoid of microfossils. Age determinations were made on the basis of rarely occurring and usually poorly preserved foraminifers and nannofossils. The faunas are contained in several thin interbeds and do not indicate much about actual accumulation rates or age limts of the unit as a whole. Most of the age determinations show that the sediments are Upper Cretaceous (Maestrichtian to Campanian). At Site 391 the lower age limit is late Albian (see Site 391 Report, this volume; Tucholke, Vogt, et al., in press). The stratigraphic position of the variegated sediments, therefore, falls somewhere between Aptian and Paleocene (possibly including the latter, in part). The lower age limit at most sites is somewhat higher Albian or Cenomanian. A prominent hiatus, which is widespread through the North Atlantic, falls within the same age limits. We do not know, however, which portion of the long time interval is occupied by the hiatus and which by sedimentation. Periods of no deposition (hiatuses) probably alternated with periods of deposition within the time period.

The accumulation rate at Site 382 for the uppermost variegated (Campanian-Maestrichtian) portion of the volcanogenic unit was $2 \mathrm{~m} / \mathrm{m}$.y., whereas underlying volcaniclastic sediments accumulated more rapidly $(12 \mathrm{~m} / \mathrm{m}$.y.). The lack of identifiable microfossils precludes estimate of the accumulation rate of the volcanogenic sediments at Site 385 (Vogel Seamount). Even if the average value of 10 $\mathrm{m} / \mathrm{m}$.y. were reasonably accurate, it could not be applied to the uppermost Coniacian-Santonian (?) silty clay of the volcanogenic unit (Cores 14, 15) which we assume corresponds with variegated claystone sequence. In Hole 386 the upper Cenomanian zeolite claystones were accumulated at relatively high rates $(18 \mathrm{~m} / \mathrm{m} . \mathrm{y}$.$) , whereas the accumulation$ rate of the uppermost (Maestrichtian?) portion of the red and variegated sequence was only $2.2 \mathrm{~m} / \mathrm{m}$.y. In Hole 387 an average value of about $5 \mathrm{~m} / \mathrm{m}$.y. was estimated for the red and variegated intervals, both in upper Maestrichtian and in upper Campanian-lower Maestrichtian sections (see Site Reports in Tucholke, Vogt, et al., in press). We could not determine the accumulation rates for the red and variegated intervals at Site 391, or Sites 101 and 105 of Leg 11.

Intervals of variegated and brown sediments are present not only in claystone deposited below the calcium carbonate compensation depth (CCD), but also in calcareous sediments of the Blake Nose (Sites 390, 392), and, less certainly, on the $J$-anomaly ridge (Site 384 , Leg 43). At Site 390, a distinct, variegated Albian and Aptian marly nannofossil ooze occurs between Maestrichtian to upper Campanian pale brown to white pure nannofossil ooze and underlying shallow-water limestone. Color bands in the variegated unit are shades of reddish brown, red, yellow, pale brown, pink, and white. The accumulation rate for the unit is estimated as $1 \mathrm{~m} / \mathrm{m}$.y. A major disconformity separates the Albian-Aptian variegated sequence from the overlying Campanian-Maestrichtian ooze.

In Hole 392A upper Campanian nannofossil and foraminifer oozes (Core 1) are variegated, although color bands (yellow, brown, pinkish) are indistinct. The oozes are underlain by lower Albian dark gray marly nannofossil ooze - a possible homolog of the basin floor black and gray claystones. A disconformity separates the two lithologic units.

At Site 384 Paleocene nannofossil ooze, mottled with brown spots and lines, is somewhat similar to variegated sediments of sub-unit $1 \mathrm{~b}$ (of Tucholke, Vogt, et al., in press). A 5-million year depositional hiatus separates this unit and the overlying lower Eocene sediments. The accumulation rate of Paleocene nannofossil ooze is 7.5 $\mathrm{m} / \mathrm{m}$.y., much lower than that of the Eocene. However, the underlying Maestrichtian nannofossil ooze has a lower accumulation rate of $4 \mathrm{~m} / \mathrm{m}$.y. Even more significant is the difference in accumulation rates of non-calcareous residues (clay and radiolarians): $0.16 \mathrm{~g} / \mathrm{cm}^{2} / 10^{3} \mathrm{yr}$ for Paleocene and $0.04 \mathrm{~g} / \mathrm{cm}^{2} / 10^{3} \mathrm{yr}$ for the Maestrichtian. Pieces of brown nannofossil ooze with Coniacian-Santonian nannofossil assemblages were found below the Maestrichtian, but the Campanian is probably absent. These brown oozes directly above shallow-water limestone may be compared with Upper Cretaceous variegated intervals at other sites.

Thus, although variable in lithology, age, and accumulation rates, the variegated and red sediments tend to occur in association with hiatuses. The accumulation rates, at least for certain portions of the intervals, are low and comparable with those of pelagic sediments. A sharp decrease in accumulation rate commonly corresponds to the transition from other lithologic types to the variegated sediments. The red and variegated sediments are not genetically related to basalt, although in some cases they overlie volcanogenic sequences or basaltic basement. The Upper Cretaceous variegated sequence directly overlies (without disconformity) the black and greenish gray carbon-rich sediments where these black clays are present.

\section{GEOCHEMISTRY}

\section{Upper Jurassic Red Limestone}

We have conducted chemical analyses of the Legs 43 and 44 red and variegated sediments (Murdmaa et al., in press; and Murdmaa et al., this volume) and compared the results to those of Leg 11 (Lancelot et al., 1972) in order to detect similarities of the sediments.

Iron - Upper Jurassic red limestone and marl in Hole $391 \mathrm{C}$ are somewhat enriched in iron compared to common hemipelagic or pelagic calcareous sediments: 0.98 per cent to 5.9 per cent of total iron was found in whole samples (average of 14 samples $3.7 \%$ ). On a carbonate-free basis this is $4.8+7.75$ per cent. Values lower than 5.8 per cent were found only in pinkish and gray interbeds. The $\mathrm{Fe} / \mathrm{Ti}$ ratio ranges from 10 to 20 . We obtained a single value of 49 in a light gray limestone interbed (Core 48, Section 1, 135$137 \mathrm{~cm}$ ), which probably contains manganic siderite. The carbonate-free iron and $\mathrm{Fe} / \mathrm{Ti}$ ratio are therefore not much higher than those in overlying gray limestone, but the latter contains less iron than in the natural rocks. Carbonate-free iron increases with increasing $\mathrm{CaCO}_{3}$ content. All iron is "insoluble"; no "soluble" amorphous hydroxides were found in the red sediments by phase analyses.

Manganese - Manganese contents in the red limestone vary widely from 0.02 to 0.79 per cent in whole samples 
and 0.02 to 2.52 per cent on a carbonate-free basis. In most cases it is somewhat higher in the red limestone than that in the overlying gray limestone. Two extreme carbonate-free values (more than $2 \%$ ) found in relatively light gray interbeds may be attributed to the presence of authigenic rhodochrozite (or manganic siderite?). Except in these two cases the manganese content does not correspond to the iron content; manganese and iron show independent behavior.

Titanium - The titanium content is low throughout the red limestone. On a carbonate-free basis it ranges from 0.17 to 0.74 per cent and is equal or somewhat lower than that found in hemipelagic clay.

Aluminum - The aluminum content ranges from 3.7 to 8.0 per cent in whole samples and from 8.3 to 9.4 per cent on a carbonate-free basis. The values are somewhat lower than those in common pelagic or hemipelagic clay, but much higher than the concentrations in aluminum-poor metalliferous sediments of active mid-oceanic ridges (Boström et al., 1969). The $\mathrm{Al} / \mathrm{Ti}$ ratio is high (18-30) in most samples analyzed. One exception is Core 50 , Section 1 , $118-120 \mathrm{~cm}$, where it is 11.9 owing to a higher titanium concentration. These are common values for terrigenous sediments of the western North Atlantic (see Murdmaa et al., in press, table 4). They are somewhat higher than those of average continental crust (15), Shales (17.5), or Pacific pelagic sediments (Boström, 1973). The $\mathrm{Fe} / \mathrm{Al}$ ratio ranges from 0.5 to 0.7 , as it does in most hemipelagic sediments of Legs 43 and 44 .

$\mathrm{SiO}_{2}$ - The $\mathrm{SiO}_{2}$ content in two analyzed samples of dark brown and red calcareous claystone is 41.8 and 41.2 per cent (on a carbonate-free basis 58.9 per cent and 54.2 per cent, respectively). The $\mathrm{SiO}_{2} / \mathrm{Al}_{2} \mathrm{O}_{3}$ ratio is 4.7 and 4.0, and is thus higher than the average of the terrigenous clay matrix. Some silicification may be responsible for the increase.

The magnesium contents in the two samples is somewhat greater $(3.19 \%$ and $3.45 \%)$ and is probably a result of dolomitization. Dolomite crystals were found in thin sections of these samples.

Trace Elements - Contents of trace elements $(\mathrm{Cu}, \mathrm{Zn}$, $\mathrm{Ni}, \mathrm{Co}$, and $\mathrm{Cr}$ ) were determined in seven samples of the red limestone (Murdmaa et al., this volume, table 3). Ranges and average values are given in Table 1 . There is no significant increase in any of the trace elements. Only nickel is somewhat higher in the red limestone than in hemipelagic sediments.

Organic Carbon - The organic carbon content in the red limestone and marl is usually low. It ranges from 0.11 to

TABLE 1

Trace Elements in the Upper Jurassic Red Limestone and Calcareous Claystones (ppm on $\mathrm{CaCO}_{3}$-free basis)

\begin{tabular}{ccr}
\hline Elements & $\begin{array}{c}\text { Range } \\
(\%)\end{array}$ & Average \\
\hline $\mathrm{Cu}$ & $23-91$ & 71 \\
$\mathrm{Zn}$ & $75-117$ & 92 \\
$\mathrm{Ni}$ & $116-212$ & 150 \\
$\mathrm{Co}$ & $30-64$ & 44 \\
$\mathrm{Cr}$ & $64-148$ & 100 \\
\hline
\end{tabular}

0.26 per cent except in one sample of low-calcareous claystone (Core 52 , Section $4,13-15 \mathrm{~cm}$ ) where it is 0.76 per cent. The carbon/carbonate data show 0.1 per cent organic carbon in most samples. Several values between 0.2 per cent to 0.6 per cent appear in the lowermost part of Hole $391 \mathrm{C}$ (Cores 49 to 52) and a single value (2.3) was found in Core 49 , Section $2,107 \mathrm{~cm}$, probably in a greenish gray layer.

\section{Cretaceous Variegated and Red Claystones}

Iron - The Cretaceous (mostly Upper Cretaceous) variegated and red claystones are usually relatively enriched in iron. In our samples maximum concentration -10 per cent of the total iron - is present in a reddish brown layer of Hole 382 , Core 16 , Section $6,45-48 \mathrm{~cm}$. The values in two yellowish orange interbeds of the variegated unit at Site 105 are 11.3 per cent and 18.6 per cent (determined by Lancelot et al., 1972, table 1). Here the data in Lancelot's et. al. Table 1 are recalculated to element concentrations, including the fraction lost on ignition, and summed to 100 per cent for comparison with our results. Iron concentrations are usually from 5 per cent to 7 per cent but lower values $(1.75 \%$ to $5 \%)$ are not uncommon. The mean of 20 samples from the variegated claystone at Site 105 is 5.84 per cent, which is about the same as occurs in pelagic clay and somewhat higher than in hemipelagic sediments. The Fe/Ti ratio shows sharp and irregular variations from 2 to 71 .

In the upper non-volcaniclastic portions of the variegated claystone at Sites 382 ( 8 samples) and 385 (6 samples) the average iron content is 5.15 per cent and 5.71 per cent, respectively. The $\mathrm{Fe} / \mathrm{Ti}$ ratio ranges from 11 to 18 . At Site 386 (Cores 35 to 41 ) the average iron content is 4.73 per cent (14 samples). Two samples of red claystone from Hole 387 , Core 29 , have 5.78 per cent and 5.54 per cent iron (Murdmaa et al., in press). At Site 391, the average iron content of different red and variegated layers (13 samples) is 5.38 per cent. The $\mathrm{Fe} / \mathrm{Ti}$ ratio ranges from 3 to 16 . A similar range of iron concentrations occurs in Aptian to Albian variegated marly nannofossil ooze from Site 390 on a carbonate-free basis: 3.14 to 6.89 per cent (averages of 7 samples $6.12 \%$ ). The $\mathrm{Fe} / \mathrm{Ti}$ ratio is usually low -6 to 8 .

The iron content in brown and variegated volcanogenic sediments of the New England Seamounts (lower portions of the "volcanogenic"' sequences at Sites 382 and 385) is appreciably higher and averages as 7.32 per cent (382) and 7.02 per cent (385). The percentage of titanium is also high $(1 \%-2.4 \%)$, so that the $\mathrm{Fe} / \mathrm{Ti}$ ratio decreases to values below 8.

Sharp variations in iron content characterize the variegated sediments. It frequently is markedly different in adjacent color bands. Brown, reddish brown, and dark yellowish orange interbeds contain relatively more iron, whereas gray, olive-gray, or yellowish gray interbeds contain relatively less iron. In Hole $391 \mathrm{C}$ (Cores 4, 5, and 6) a greenish gray layer contains 4.9 per cent iron $(\mathrm{Fe} / \mathrm{Ti}$ ratio $=$ 10.9), dark brown and reddish brown layers contain 6.2 and 5.7 per cent iron, respectively $(\mathrm{Fe} / \mathrm{Ti}$ ratio $=13.8$ and 12.9, respectively). In Core 10 of the same hole we analyzed thin olive-gray and brown laminae from a single 3 -cm-thick interval $(10-2,108-111 \mathrm{~cm})$. The former has 4.0 per cent iron $(\mathrm{Fe} / \mathrm{Ti}$ ratio $=3.0)$, the latter has 6.5 per cent iron $(\mathrm{Fe} / \mathrm{Ti}$ 
ratio $=5.4$ ). In Hole $391 \mathrm{~A}$, Core 21 the differences are even greater: 4.1 per cent to 4.7 per cent iron in gray or olive-gray layers; 6.2 per cent in a dark brown, and 8.8 per cent in a dark yellowish orange ("rusty") layer.

The colors of the individual samples analyzed in the Leg 11 , Site 105 variegated claystone were not given, but I infer from the core descriptions that the lower values usually are from gray, yellowish gray, or light grayish brown layers, whereas the higher values are from yellowish brown and dark yellowish orange layers. The variations of the $\mathrm{Fe} / \mathrm{Ti}$ ratio are particularly great in Core 9 , Section 2 , from which six samples were analyzed. The ratio ranges from 4.2 to 71.0 , which is mainly caused by differences in iron content. An unusually low iron content $(1.67 \%-2.59 \%)$ in several layers, accompanied by very low $\mathrm{Fe} / \mathrm{Ti}$ ratios (2.4-4.2) and $\mathrm{Fe} / \mathrm{Al}$ ratios $(0.17-0.23)$ probably indicates leaching, although in some layers it may be a result of dilution by detrital quartz (Lancelot et al., 1972).

The variations in the iron content between different color bands are less distinct in the uppermost (non-volcanogenic) variegated claystones at Sites 382 and 355 . In Hole 382, Core 15 , Sections 5 and 6 , for example, the iron ranges between 3.88 per cent to 5.23 per cent $(\mathrm{Fe} / \mathrm{Ti}$ ratio $=11$ to 18). In the lower volcaniclastic part of the variegated sequence the iron content (on a carbonate-free basis) shows rather minor variations. Because of the differences in titanium contents the $\mathrm{Fe} / \mathrm{Ti}$ ratio is more variable. Phase analyses on the iron indicate that the increase in total iron is produced mainly by "soluble" $\mathrm{Fe}_{+}{ }^{3}$, i.e., geochemically mobile amorphous or poorly crystallized hydroxides. Contents up to 4.9 per cent of the "soluble" $\mathrm{Fe}_{+}{ }^{3}$ (or up to $73 \%$ of total iron) were determined. Insoluble $\mathrm{Fe}_{+}{ }^{3}-$ that of silicates and crystalline iron oxides - ranges in these sediments from 1.8 per cent to 5.5 per cent. A large portion of iron was therefore released from the primary volcaniclastic rocks during alteration, but rather minor diagenetic migration of the free hydroxides has also taken place.

In the variegated sediments at Sites 386 and 387 rather sharp variations in iron were found at some intervals. For example, in Hole 386, Core 38, Section 2, two adjacent samples, 146-147 cm (dark brown) and 149-150 (light reddish brown) have total iron contents of 4.4 per cent and 3.3 per cent, respectively. The Fe/Ti ratios are 17.6 and 13.3. Sample 40-2, 0-2 cm (light greenish gray noted as "bleached") contains 2.75 per cent iron ( $\mathrm{Fe} / \mathrm{Ti}$ ratio = $13.1, \mathrm{Fe} / \mathrm{Al}$ ratio $=0.53)$. The adjacent red layer $(3-4 \mathrm{~cm})$ contains 6.48 per cent iron $(\mathrm{Fe} / \mathrm{Ti}$ ratio $=27 ; \mathrm{Fe} / \mathrm{Al}$ ratio $=$ $0.95)$. These variations may be caused by diagenetic leaching and migration of iron. Iron ranges from 4.5 to 6.5 per cent in the brown and red layers, and 2.75 to 4.5 per cent in light brown and gray layers. Insoluble $\mathrm{Fe}+$ in the brown and red layers ranges from 2.7 to 5.1 per cent. Up to 2 per cent of soluble $\mathrm{Fe}_{+}{ }^{3}$ were found in these layers in contrast with underlying black and gray claystones, where it is absent.

Manganese - The manganese content in the Cretaceous variegated and red sediments is variable. It ranges from 0.01 to as high as 4.25 per cent. Lowest values characterize all the gray layers, obviously a result of leaching in reducing conditions. Brown and red layers commonly have higher manganese contents than the hemipelagic clay above or black and greenish gray claystones below. The manganese content is distinctly different in adjacent color bands. For example, striking contrasts are shown on Table 2 in a series of samples from Hole 391A, Core 21, Section 1. Here manganese contents differ by as much as a factor of 85 , without any corresponding changes in manganese and iron and with no visible changes in lithology (except color). In Hole 382, Core 15 , Section $6,44-47 \mathrm{~cm}$, dark and light brown layers were separately analyzed. The iron content is almost the same in both samples $(4.16 \%$ and $4.43 \%)$, but the manganese content in the dark layer is three times higher than that in the light layer $(0.54 \%$ versus $0.15 \%)$. We obtained the same results from Core 16 , Section $1,94-98 \mathrm{~cm}$ (dark) and $100-107 \mathrm{~cm}$ (light). The iron content is 5 per cent and 4.65 per cent, respectively; the manganese content is 0.76 per cent and 0.09 per cent, respectively. In Hole 385, Core 15 , Section 1 , four samples from different color bands between $53 \mathrm{~cm}$ and $150 \mathrm{~cm}$ contain almost equal amounts of iron $(5 \%$ to $6.7 \%)$, but variable amounts of manganese content $(0.19 \%$ to $1.36 \%)$. In Hole 386 , Core 39 , Section 1 , $129-145 \mathrm{~cm}$ the iron in three samples (light to dark brown) ranges from 4.95 per cent to 5.98 per cent, whereas the manganese contents are $0.08,0.28$, and 0.76 per cent. The $\mathrm{Mn} / \mathrm{Ti}$ ratio in the same samples is $0.2,1.3$, and 2.7 , respectively.

Thus, in the variegated sediments, variations in manganese contents are much greater than those of iron and contents of the two elements do not parallel each other. Migration of reduced $\mathrm{Mn}^{+2}$ in interstitial water and its precipitation as $\mathrm{MnO}_{2}$ during diagenesis of sediments probably best explains these features. Manganese is known to be more mobile in diagenesis than iron, as reduction of $\mathrm{Mn}_{+}{ }^{4}$ to soluble $\mathrm{Mn}^{+2}$ takes place under higher Eh conditions. The manganese was apparently leached not only from gray layers, but also from most yellowish and reddish brown ferruginous layers. For example, in Hole 391C, Core 10, Section 2, 108-111 cm, adjacent brown and gray layers contain only 0.04 per cent and 0.08 per cent manganese, but iron in the brown layer comprises 6.5 per cent and 4 per cent in the gray layer.

Titanium - The titanium content, as noted above, is a good indicator of volcaniclastic constituents in the Upper Cretaceous sequence at the New England Seamounts (Sites 382 and 385). Alkaline basalts of the seamounts are rich in titanium (Tucholke, Vogt, et al., in press). Our analyses of two samples (Murdmaa et al., in press) of volcaniclastic breccia from Hole 382 show 1.6 and 1 per cent titanium (on $\mathrm{CaCO}_{3}$-free basis, excluding cementing carbonate). The $\mathrm{Al} / \mathrm{Ti}$ ratio is 5.9 and 7.0 , respectively. In a sample of ferruginous volcaniclastic sand the titanium content is 2.5 per cent ( $\mathrm{Al} / \mathrm{Ti}$ ratio equals 2.4$)$. Throughout the entire variegated and red volcaniclastic siltstone and claystone se-

TABLE 2

Iron and Manganese in Hole 391A Core 21

\begin{tabular}{cccl}
\hline $\begin{array}{c}\text { Interval } \\
(\mathrm{cm})\end{array}$ & $\begin{array}{c}\mathrm{Mn} \\
(\%)\end{array}$ & $\begin{array}{c}\mathrm{Fe} \\
(\%)\end{array}$ & \multicolumn{1}{c}{ Color } \\
\hline $15-19$ & 0.56 & 4.99 & Dark brown with black \\
$47-50$ & 4.25 & 3.58 & Brownish black \\
$63-67$ & 0.05 & 4.43 & Gray \\
$75-79$ & 0.55 & 4.69 & Dark yellowish gray \\
\hline
\end{tabular}


quences at Sites 382 and 385 , titanium contents range from 0.8 per cent to 2.5 per cent; the $\mathrm{Al} / \mathrm{Ti}$ ratio equals from 2.4 to 8.1 . Thus, the high titanium content was not only preserved during reworking of the primary volcaniclastic sediments, but was considerably increased in some sediment layers. The increase may be caused by low geochemical mobility of titanium during hydrothermal alteration or by weathering of basalts and diagenesis of sediments. Residual enrichment, however, hardly explains the increase of titanium by a factor of 2 to 2.5 and some active processes of titanium concentration must have taken place.

Because of the high titanium content, the $\mathrm{Fe} / \mathrm{Ti}$ and $\mathrm{Mn} / \mathrm{Ti}$ ratios in the volcaniclastic sequences are extremely low and do not indicate the relative concentration in the sediments of either iron or manganese.

In the upper variegated claystones in Holes 382 and 385 (non-volcaniclastic), as well as in other variegated and red sediments of Holes 105, 386, 387, 390, 391A, and 391C, the titanium contents are commonly between 0.25 per cent to 0.6 per cent, nearly equal to those in terrigenous hemipelagic and pelagic clay. However, some layers with greater amounts of titanium $(0.7 \%-1.3 \%)$ are present in Holes 105 (Core 8), 390 (Core 3, Section 1, 68-70 cm and 146-148 cm), 390A (Core 14, Section 5, 144-147 cm), 391A (Core 21, Sections 1, 2 - all analyzed samples), 391C (Core 10, Sections 1, 2 - three analyzed samples). Contents between 0.6 per cent to 0.8 per cent were found in several samples at sporadic intervals. The increase in titanium may be interpreted either as evidence of admixture of alkaline-basaltic volcaniclastic matter or as a peculiarity of the terrigenous source clay. Regardless of its source, it leads to dimunition of $\mathrm{Fe} / \mathrm{Ti}$ and $\mathrm{Mn} / \mathrm{Ti}$ ratios even in samples with high concentrations of iron and manganese.

The titanium contents do not appear to be related to different color bands. In Hole 391C, Core 10, Section 2 , 108-111 cm, for example, both gray and brown layers are relatively high in titanium $(1.2 \%$ and $1.32 \%)$. Greenish gray, reddish brown, dark brown, and black layers in Cores 4,5 , and 6 of the same hole are equally low in titanium $(0.4 \%-0.46 \%)$.

Aluminum - The aluminum content in the variegated and red claystones is highly variable, but tends to be greater than that in the hemipelagic sediments above and below.

In Hole 105 (Lancelot et al., 1972, table 1) aluminum ranges from 4.1 to 12 per cent; values higher than 9 per cent predominate. Several samples from silt or sand layers contain very little aluminum (less than $6 \%$ ). In the same samples, the $\mathrm{Al} / \mathrm{Ti}$ ratios are low (4.3-10.6) and probably indicate the presence of relatively abundant titanium-bearing detrital minerals. Three samples of ferruginous sediments in Cores 5 and 9 are also rather low in aluminum (5.9\% to $7.2 \%)$, but contain very little $\mathrm{SiO}_{2}\left(\mathrm{SiO}_{2} / \mathrm{Al}_{2} \mathrm{O}_{3}\right.$ ratio equals 3.3-3.7). These three samples are somewhat similar geochemically to the low-aluminum metalliferous sediments of hydrothermal origin. The $\mathrm{Fe} / \mathrm{Al}$ ratios here are 1.9 to 3.2 ; the $\mathrm{Fe} / \mathrm{Ti}$ ratios are 28.8 to 71.0 . The $\mathrm{SiO}_{2} / \mathrm{Al}_{2} \mathrm{O}_{3}$ ratio, however, equals that of common pelagic clay and does not increase as a result of decrease in aluminum. This situation is unlike to that in the East Pacific Rise or Red Sea metalliferous sediments (Bischoff, 1969; Böstrom, Peterson et al., 1969; Lisitzyn et al., 1976). Most samples are instead of the "'high-aluminum"' variety. The Fe/Al ratios in these sediments are below 0.8 (the mean for deep-sea sediments), and are commonly 0.4 to 0.6 or lower. The $\mathrm{Al} / \mathrm{Ti}$ ratios are high (17 to 40,74 in one sample), and are equal or higher than the mean for deep-sea sediments (18.2) or shales (17.5).

Variegated claystones above the volcaniclistic sequence of the New England Seamounts (Site 382, Cores 15 to $16-1,0-3 \mathrm{~cm}$; Site 385 , Cores 14-15) are slightly enriched in aluminum (9.3\%-12.9\%); whereas the volcaniclastic sediment itself is rather low in aluminum (4.9\%-9.2\%). The $\mathrm{Al} / \mathrm{Ti}$ ratios show even greater differences. The ratios are high in the upper claystone (20-37) which belong to the "high aluminum" variety, and are sharply lower (to 1.4$10.5)$ in the titanium-rich volcaniclastic sediments and volcaniclastic breccia (5.9-7.0). The $\mathrm{Fe} / \mathrm{Al}$ ratios in the upper variegated claystones $(0.4-0.6)$ are normal values for terrigenous clay; those of volcaniclastic sediments are somewhat higher (0.6-1.8); a single extreme value is 2.9. In the volcaniclastic breccia the $\mathrm{Fe} / \mathrm{Al}$ ratio equals 1.0 to 1.1 . The $\mathrm{SiO}_{2} / \mathrm{Al}_{2} \mathrm{O}_{3}$ ratio ranges from 2.5 to 3.5 and is not distinctly different in the two lithologic varieties. Intermediate values, 2.9 and 3.2, characterize the volcaniclastic breccia at Site 382 . The basaltic composition of the volcaniclastic breccia is responsible for its relatively low-aluminum contents and the characteristic ratios with aluminum. No influence from exhalative matter can be inferred from the data.

In the variegated sediments of Hole 386 (Cores 35 to 41 ) the aluminum content ranges from 4.8 per cent to 10.7 per cent; the lower values apparently result from dilution by silica, as indicated by "normal" or high $\mathrm{Al} / \mathrm{Ti}$ ratio (18.7 to 28.3 ) and by considerably greater amounts of $\mathrm{SiO}_{2}$ in the low-aluminum samples $(63 \%-71 \%)$. The $\mathrm{SiO}_{2} / \mathrm{Al}_{2} \mathrm{O}_{3}$ ratios range from 2.7 to 7.8. Two low values (2.8 and 2.7$)$ were obtained in Core 36, Section 5, 74-76 cm and 94-98 cm, where $\mathrm{SiO}_{2}$ equals 52.8 per cent and 52.7 per cent, respectively, and $\mathrm{Al}_{2} \mathrm{O}_{3}$ equals 19.1 per cent and 19.4 per cent, respectively. These two samples were taken from dusky red homogeneous claystone from the uppermost red Maestrichtian part of the variegated sediments, just below a probable hiatus. The samples are geochemically most similar to the "high-aluminum" claystones of Holes 105, 382, and 385. Except for these samples, the $\mathrm{SiO}_{2} / \mathrm{Al}_{2} \mathrm{O}_{3}$ ratio is high throughout the lower part of the variegated sequence (4.5-7.8), and is similar to that in the underlying black and gray claystone. The $\mathrm{Fe} / \mathrm{Al}$ ratio ranges from 0.5 to 0.8 ; we obtained a single value of 1.0 in Core 40 , Section $2,3-4 \mathrm{~cm}$.

In Hole 387 , Core 29, red and dark brown claystones are high in aluminum. Two samples have 11.5 and 12.2 per cent aluminum; the $\mathrm{Al} / \mathrm{Ti}$ ratio is 24 and 30 , respectively. The $\mathrm{SiO}_{2} / \mathrm{Al}_{2} \mathrm{O}_{3}$ ratio in one sample is 2.8; the $\mathrm{Fe} / \mathrm{Al}$ ratio is 0.5 and 0.4 The claystones thus belong to the "high-aluminum" variety, mentioned above. 
The aluminum content is relatively high $(9.3 \%$ to $11.5 \%)$ in the red and variegated sediments in Holes $391 \mathrm{~A}$, Core 21 and $391 \mathrm{C}$, Cores 6 and 10 . The same values predominate in gray and black layers between Cores 6 and 10, Hole $391 \mathrm{C}$. The $\mathrm{Al} / \mathrm{Ti}$ ratio in Hole $391 \mathrm{~A}$, Core 21 and Hole 391C, Core 10 is low (7.110.2) and is somewhat similar to that in the volcaniclastic sediments of Holes 382 and 385 , described above. In Cores 6 to 8 (black claystone) the ratio is much higher (21-27) on the same level of aluminum percentage. The $\mathrm{SiO}_{2} / \mathrm{Al}_{2} \mathrm{O}_{3}$ ratio is somewhat lower than "normal" (2.8-3.1) in Hole 391A, Core 21 and is similar to that of both the volcaniclastic sediments and the "high-aluminum", claystone. Values of 3.0 to 3.6 were obtained in other samples from the variegated sediments. The $\mathrm{Fe} / \mathrm{Al}$ ratio is low or "normal", (0.4-0.9) throughout the interval.

The aluminum contents in carbonate-free residue of the variegated marly nannofossil ooze in Hole 390, Core 3 and Hole $390 \mathrm{~A}$, Core 14 (two analyzed samples) is 10.9 and 8.4 per cent, respectively. The $\mathrm{Al} / \mathrm{Ti}$ ratios are rather low (14 and 8.3) and the $\mathrm{Fe} / \mathrm{Al}$ ratios are 0.6 and 0.7 , respectively.

Some aluminum was found in solution following treatment, during phase analyses of iron, of the samples with Tamm's reagent. Thus, some soluble forms of aluminum are probably present in the variegated sediments. The "soluble" $\mathrm{Al}_{2} \mathrm{O}_{3}$ is highest $(2.1 \%)$ in brown marly nannofossil ooze from Hole 390, Core 3, Section 1, 68-70 cm. Aluminum contents of 0.25 to 1.70 per cent are present in volcaniclastic and non-volcaniclastic variegated claystones of Holes 382 and 385 ; 0.53 and 1.38 per cent in red claystones of Hole 387 , Core 29; 0.88 per cent in a brown interbed in Hole 391C, Core 10, Section 2, 108-111 cm; 0.23 per cent and 1.55 per cent in Hole 391A, Core 21, Section 2.

Silica - Silica $\left(\mathrm{SiO}_{2}\right)$ contents vary from low $(36 \%$ $50 \%$ ) to "normal" values for clay (51\%-57\%) up to high $(60 \%-79 \%)$ values. The highest values, no doubt result from the presence of siliceous phases in addition to those in clay. The low values are common in volcaniclastic sediments at Sites 382 and 385 ; the $\mathrm{SiO}_{2} / \mathrm{Al}_{2} \mathrm{O}_{3}$ ratio here is also low (2.5 to 3.2). Some high-iron samples of Hole 105 are low in silica (38\%-44\%) (Lancelot et al., 1972). They have been diluted by iron minerals which comprise 20 to 40 per cent of the sediments. The $\mathrm{SiO}_{2} / \mathrm{Al}_{2} \mathrm{O}_{3}$ ratio, in this case, does not decrease (3.4-3.7). On the contrary, most of the variegated sediments in Hole 105 are enriched in $\mathrm{SiO}_{2}$ $(57 \%-79 \%)$. The $\mathrm{SiO}_{2} / \mathrm{Al}_{2} \mathrm{O}_{3}$ ratios in several samples, however, are higher than 4 (up to 10.2); these samples are rich in detrital quartz. Other samples are high in both $\mathrm{SiO}_{2}$ and $\mathrm{Al}_{2} \mathrm{O}_{3}$, so the ratio is "normal" or even low (2.9-3.5). In Hole 386 almost the entire variegated sequence below Core 36 is enriched in $\mathrm{SiO}_{2}$. Silica contents of 60.8 per cent to 71.8 per cent were found in Cores 37 through 41 (mean $66.4 \%$ ). The $\mathrm{SiO}_{2} / \mathrm{Al}_{2} \mathrm{O}_{3}$ ratio ranges from 4.5 to 7.8 (mean 6.1). High silica, with respect to aluminum, results here from authigenic silicification: the presence of cristobalite and quartz (chalcedony) was determined by X-ray diffractometry (Koch and Rothe, in press).

"Normal" values of $\mathrm{SiO}_{2}(50 \%-57 \%)$ characterize most non-volcanic and non-silicified variegated claystones in Holes 105, 382 (Core 15), 385 (Cores 14-15), 386 (Core 36), 387, 391A, 391C. $\mathrm{SiO}_{2} / \mathrm{Al}_{2} \mathrm{O}_{3}$ ratio ranges from 2.5 to
3.7. Low values (less than 3) indicate the presence of a high-aluminum clay matrix.

Thus, there are no distinct features in the $\mathrm{SiO}_{2}$ distribution, peculiar to the variegated sediments. Increase in $\mathrm{SiO}_{2}$ from increased terrigenous quartz or diagenetic silicification, and low values from basaltic volcaniclastics, or values close to those of average clay, are not necessarily associated with these lithofacies.

Magnesium - Magnesium (expressed as $\mathrm{MgO}$ ) contents range from 1.3 to 3.9 per cent in most samples analyzed from the variegated claystone which is similar to that found in hemipelagic clay. It is somewhat higher (up to $9.1 \%$ ) in the volcaniclastic sediments of Holes 382 and 385 .

Potassium - Potassium $\left(\mathrm{K}_{2} \mathrm{O}\right)$ commonly comprises between 2 and 3.5 per cent, and increases up to 5.2 per cent in the volcaniclastic sediments of Holes 382 and 385 .

$\mathrm{CaO}-\mathrm{CaO}$ comprises less than 1 per cent in the noncalcareous variegated sediments of Holes 105, 386, 387, $391 \mathrm{~A}$, and $391 \mathrm{C}$ and in the upper non-volcaniclastic part of the sequence in Holes 382 and 385 . Volcaniclastic sediments in these holes contain more $\mathrm{CaO}$ ( $1 \%$ to $4.5 \%$ ).

Trace Elements - None of the analyzed trace elements increases regularly in the Cretaceous variegated and red sediments (Table 3 ). High concentrations of copper and nickel only occur seldomly at Sites 105, 390, and 391 . Although distinct variations frequently occur within each of the variegated intervals, most values are similar to those in other hemipelagic and pelagic sediments of the western North Atlantic. These variations show us that quite complicated relationships exist between the trace elements and major constituents of the sediments. In addition to dilution by detrital quartz, biogenic and authigenic carbonate, authigenic silica, and zeolites (?), which affects the concentrations of all trace elements almost equally, numerous distinct relative changes in their concentrations also occur. These changes are probably related to diagenetic migration and/or sorption-desorption processes involving species such as iron and manganese hydroxides, and clay minerals. So relatively high concentrations of nickel and colbalt definitely correlate with increased manganese concentrations in several dark brown layers and spots in the variegated sediments from Hole 105, the upper variegated claystones of Hole 385 (Core 15), and in Hole 386. Some higher concentrations of nickel in Holes 382 and 105 are not related to manganese. Nickel concentrations vary widely in the volcaniclastic sediments at Sites 382 and 385 , but we detect no correlation between the occurrence of nickel and manganese. Close association of nickel with manganese is characteristic of pelagic sediments and manganese nodules, where the association is related to sorption of hydrogeneous nickel on manganese dioxide. Very low nickel (less than $50 \mathrm{ppm}$ ) and cobalt (less than $20 \mathrm{ppm}$ ) concentrations in several samples from Sites 105 and 382 probably indicate leaching during diagenesis.

The upper variegated claystones at Sites 382 and 385 and several layers at Site 105 are somewhat enriched in both zinc and copper. Zinc, however, increases independently of copper in some samples from Sites 386, 387, and 390 and in the volcaniclastic sediments at Sites 382 and 385. Zinc enrichment commonly parallels increased iron concentrations.

Chromium contents vary sharply in Holes 105 and 386 and in the lower volcaniclastic sediments at Sites 382 and 385. This, in addition to prevalence of unusually low con- 
TABLE 3

Trace Elements in the Cretaceous Variegated and Red Sediments (ppm)

\begin{tabular}{ccccccccccc}
\hline & \multicolumn{2}{c}{$\mathrm{Cu}$} & \multicolumn{2}{c}{ Zn } & \multicolumn{2}{c}{$\mathrm{Ni}$} & \multicolumn{2}{c}{ Co } & \multicolumn{2}{c}{ Cr } \\
Location & Range & Avg. & Range & Avg. & Range & Avg. & Range & Avg. & Range & Avg. \\
\hline Site 105 $(19)^{\mathrm{a}}$ & $31-779$ & 163 & $43-248$ & 146 & $8-472$ & 79 & $2-155$ & 23 & $9-327$ & 138 \\
Sites 382. 385: & & & & & & & & & & \\
Upper $(10)^{\mathrm{b}}$ & $50-155$ & 108 & $117-156$ & 137 & $74-152$ & 112 & $14-105$ & 45 & $80-132$ & 100 \\
Lower (20) & $31-96$ & 57 & $65-215$ & 107 & $38-160$ & 71 & $24-92$ & 42 & $40-200$ & 71 \\
Site 386 (10) & $41-120$ & 69 & $54-148$ & 93 & $51-156$ & 90 & $30-85$ & 54 & $35-130$ & 66 \\
Site 387 (2) & $45-100$ & - & $118-120$ & - & $90-101$ & - & $19-20$ & - & $93-98$ & - \\
Site 391 (9) & $26-240$ & 104 & - & - & - & - & - & - & - & - \\
Site 390 (7) & $33-76$ & 54 & $116-236$ & 153 & $63-206$ & 113 & - & - & $93-172$ & 122 \\
\hline
\end{tabular}

${ }_{b}^{\mathrm{a}}$ Numbers in parentheses $=$ number of analyzed samples.

b"Upper" = non-volcanigeneous part.

c "Lower" = volcaniclastic part.

${ }^{\mathrm{d}}$ Carbonate-free basis.

centrations at Sites 382 and 385 despite high chromium contents in basalts, suggests that the chromium was geochemically very mobile. Removal of chromium, as well as nickel from the basaltic volcaniclastics probably took place in strongly oxidizing conditions during their alteration to clay and zeolites.

Organic Carbon - The organic carbon content in the variegated and red sediments is commonly very low. In Holes 105, 382, 385, 386, and 387 (Tucholke, Vogt, et al., in press) only zero or 0.1 per cent organic carbon is present. (Determinations were made on a Leco Analyzer.) Our data range from 0.3 to 0.07 per cent (Hole 382). At Site 391 the organic carbon content is somewhat higher, ranging from 0.1 to 0.6 per cent. Two values of 0.6 per cent in Hole $391 \mathrm{C}$, Core 6 were probably obtained from dark gray interbeds. Thus, the total organic matter content is comparable to the lowest values found in pelagic clay and differ sharply from that of adjacent lithologic units, especially the underlying black shales.

In conclusion of the geochemical review, I emphasize that an additional exhalative source of metals is not necessary to explain the observed chemical features of the Upper Jurassic and Cretaceous variegated and red sediments. Their concentration may be explained in terms of pelagic sedimentation and by reworking of altered volcaniclastic matter with subsequent diagenetic migration of $\mathrm{Fe}, \mathrm{Mn}, \mathrm{Zn}$, $\mathrm{Cu}, \mathrm{Ni}, \mathrm{Co}$, and $\mathrm{Cr}$ in contrasting redox conditions.

The variegated and red sediments are divided into three geochemical varieties according to their major constituents. (1) The "high-aluminum" variety, mentioned above, is widespread although it forms rather thin layers. It is characterized by high aluminum concentrations ( $9 \%-12 \%)$, and $\mathrm{Al} / \mathrm{Ti}$ ratio (17-40), a low $\mathrm{SiO}_{2} / \mathrm{Al}_{2} \mathrm{O}_{3}$ ratio (2.4-3.3), and decreased $\mathrm{Fe} / \mathrm{Al}$ and $\mathrm{Mn} / \mathrm{Al}$ ratios (even in sediments with relatively high iron and manganese). (2) The "hightitanium" variety is found in lower volcaniclastic sequences at Sites 382 and 385 and is probably also present at Hole 105 (Core 8) and Holes 391A (Core 21), 391C (Core 10). The titanium content in these sediments is higher than 1 per cent and the $\mathrm{Al} / \mathrm{Ti}$ and $\mathrm{Fe} / \mathrm{Ti}$ ratios are low (less than 10). (3) The "high-silica" variety has $\mathrm{SiO}_{2}$ contents and $\mathrm{SiO}_{2} /$ $\mathrm{Al}_{2} \mathrm{O}_{3}$ ratios markedly higher than those of hemipelagic or pelagic clay. It probably includes two different types - one rich in detrital quartz (Site 105), the other silicified quartz (Site 386). The $\mathrm{SiO}_{2}$ in both cases dilutes the iron, titanium, and trace elements. The characteristic ratios of iron and manganese with titanium and aluminum in any of the three varieties have no resemblance to those in active ridge exhalative metalliferous sediments.

\section{MINERALOGY}

I have utilized several sources of data to characterize and compare the red and variegated sediments drilled during Legs 11,43 , and 44 . These include X-ray data from Zemmels et al. (1972), Koch and Rothe (in press), Flood (this volume), results of optical mineralogy by Lancelot et al. (1972), and shipboard coarse fraction, smear-slide, and thin-section descriptions.

Clay Minerals - The variegated sediments are dominantly clay or silty clay (claystone) in which clay minerals constitute a significant portion of their composition. In Hole 105 , Cores 5 to 9, the Upper Cretaceous variegated sediment differs from underlying black and gray claystones by its increased kaolinite content (10\% to $25 \%$ ) and decreased montmorillonite content ( $26 \%$ to $64 \%$ ); montmorillonite dominates downhole (Zemmels et al., 1972, table 8). The same features are even more distinct in "special samples" (table 11, Zemmels et al., 1972). The kaolinite concentrations of 20 to 25 per cent are unmatched in any other sample from Hole 105. This interval seems to correspond with the "high-aluminum" variety of claystone noted above. Chlorite is virtually absent.

Clay mineral contents vary in the volcanogenic sediments of the New England Seamounts (Sites 382, 385), however, the lower volcaniclastic (high-titanium) zones differ distinctly from the upper non-volcaniclastic (high-aluminum, low titanium) zones. Montmorillonite decreases in the upper non-volcaniclastic sediments and comprises 29 to 73 per cent of the crystalline phase of the $<2 \mu \mathrm{m}$ fraction. Mica is more common (15\%-40\%) and kaolinite was found in quantities 7 to 29 per cent; the chlorite is low $(3 \%-10 \%)$. In the volcaniclastic zones several layers in Hole 382, Core 18 (calcareous variegated clay) have similar mineral assemblages characterized by relatively abundant kaolinite 
$(10 \%-22 \%)$ and mica $(28 \%-57 \%)$, and relatively less montmorillonite. In other intervals, montmorillonite strongly predominates, in most cases comprising $100 \%$ of the fraction.

In Hole 386 a characteristic kaolinite-mica association with relatively less montmorillonite occurs in the upper part of the variegated sequence (Cores 35-36). The red claystones of this interval are the "high-aluminum" variety (more than $10 \% \mathrm{Al}$ ). The lower part (Cores 38 to 41 ) is characterized by a mica-montmorillonite association with minor amounts of kaolinite and chlorite (less than 10\%). This interval falls in the "high siliceous variety." X-ray data show the presence of clinoptilolite and disordered cristobalite which indicates diagenetic silicification (Koch and Rothe, in press).

In Hole 387, Core 29 (red claystone) kaolinite comprises 14 and 27 per cent; mica 41 per cent and 56 per cent; chlorite 10 per cent and 17 per cent; montmorillonite 35 per cent and 0 per cent; thus again showing a kaolinite-micamontmorillonite assemblage in a high-aluminum claystone.

Flood (this volume) determined only the bulk mineral composition by X-ray diffractometry in the Leg 44 samples; consequently the clay mineral assemblages could not be identified. However, large percentages of mica and kaolinite were noted in each of the red and variegated lithologies. At Site 390, in Albian-Aptian variegated marly nannofossil ooze, mica constitutes 2 to 11 per cent, and kaolinite constitutes 1 to 4 per cent of the total 6 to 18 per cent of the clay minerals. In Hole 391A the variegated sediment in Core 21 is appreciably enriched in kaolinite $(7 \%-10 \%)$ and mica $(22 \%-28 \%)$ and is relatively low in montmorillonite $(0 \%-$ $17 \%)$. The mica and kaolinite increases among the clay minerals in variegated and red sediments of Hole 391C (Cores 4 to 6 and 10) as compared with adjacent layers above and below.

$\mathrm{X}$-ray determinations by Pastouret and Chamley (this volume) show a sharp increase in kaolinite in the Upper Cretaceous red claystone of Hole 391A, Core 21, and in Maestrichtian and Campanian nannofossil ooze with a corresponding decrease in smectite.

The total clay mineral content in the Upper Jurassic red marl in Hole 391C is not sufficient to allow interpretation of quantitative interrelations between clay minerals. In most samples, however, mica and montmorillonite seem to occur in almost equal amounts, with minor amounts of kaolinite present. In Hole 105 (Zemmels et al., 1972, table 8) a distinct downhole increase in mica corresponds to a decrease in montmorillonite in Upper Jurassic sediments at the boundary between gray and underlying red limestones. In Hole 100A (Zemmels et al., 1972, table 3), the same stratigraphic transition is marked by a downhole increase in mica and palygorskite, whereas the lower boundary of the red limestone corresponds to sharp increase in montmorillonite and decrease in palygorskite.

Quartz and Feldspar - These detrital minerals and their interrelationships are particularly important as indicators of source material and depositional environments.

Leg 11 X-ray data (Zemmels et al., 1972, table 8) show that quartz strongly predominates over feldspars (by factors of 2.5 to 10) in both Upper Cretaceous and Upper Jurassic variegated sediments at Sites 100 and 105. In Upper Jurassic red limestone the quartz to feldspar $(\mathrm{Qz} / \mathrm{Fe})$ ratio ranges between 3.5-10; feldspar is represented only by plagioclase. In the Upper Cretaceous limestones (Site 105) the quartz content ranges from 17.5 to 33.6 per cent, and is higher than that in underlying black claystone. The plagioclase content is 2.4 to 7.5 per cent; $\mathrm{K}$-feldspar is 0 to 6.2 per cent, and the $\mathrm{Qz} / \mathrm{Fe}$ ratio is $2.5-4$, similar to that in the black claystone.

In Hole 391C the Upper Jurassic red marl contains 14 to 22 per cent quartz, 0 to 8 per cent plagioclase, and 0 to 4 per cent K-feldspar (Flood, this volume). Thus, it is similar to the red marl at the Leg 11 sites. The quartz content on the carbonate-free basis (carbonates determined from X-ray data) is 22 to 100 per cent. Enormous amounts of quartz in the non-calcareous residue of the limestones may have resulted from authigenic silicification (chalcedonization). Thin veinlets and lenses of chalcedony, as well as clastic quartz grains and rare poorly preserved recrystallized radiolarians are present in the thin sections. A high quartz and chalcedony content apparently causes an increase of $\mathrm{SiO}_{2}$ and a higher $\mathrm{SiO}_{2} / \mathrm{Al}_{2} \mathrm{O}_{3}$ ratio.

The Cretaceous variegated sediments at Site 391 contain 29 to 58 per cent quartz (Flood, this volume). Plagioclase ranges from 5 to 16 per cent, and $\mathrm{K}$-feldspar ranges from 0 to 8 per cent. The $\mathrm{Qz} / \mathrm{Fe}$ ratio ranges from 1.8 to 10.5 . We detected abundant silt and sand-size, angular clastic quartz grains in thin sections of these intervals. Plagioclase, microcline, and perthite grains were also present in minor quantities. Detrital minerals are distributed unevenly and are concentrated in thin laminae or lenses interbedded with pure clay. Quartz predominates over feldspar in the coarse fraction $(0.1-0.05 \mathrm{~mm})$.

$\mathrm{X}$-ray analyses of the Cretaceous variegated sediments, drilled during Leg 43 (Koch and Rothe, in press), show that the quartz content and quartz to feldspar relationships are similar in Holes 386 and 387 and in the upper nonvolcaniclastic layers of Holes 382 and 385, whereas those in volcaniclastic sequences of the New England Seamounts are quite different. Non-volcaniclastic sediments are characterized by a quartz content in bulk samples 9 to 20 per cent (average of 17 samples is 13\%; two obviously silicified samples in Hole 386, Core 41 are excluded). The feldspar content is 2 to 8 per cent and the $\mathrm{Qz} / \mathrm{Fe}$ ratio is 2 to 7.5 . Quartz is also more abundant than feldspars in the coarse fraction (Murdmaa, in press). Quartz is virtually absent in the volcaniclastic sediments at Sites 382 and 385 except in a few calcareous interbeds where it comprises 3 to 14 per cent; feldspar comprises 0 to 14 per cent.

Heavy Minerals - Only rare grains of detrital heavy minerals - pyroxene, hornblende, mica, and magnetite (?) - were found in the Upper Jurassic red marl and limestone at Sites 100, 105, and 391. Lancelot et al. (1972), however, noted authigenic rutile, barite, and hematite in Hole 105.

Heavy minerals are rare in the non-volcaniclastic Cretaceous variegated claystones at Sites 382,385 , and 386 . Clinopyroxene commonly predominates and garnet, hornblende, orthopyroxene, epidote, spinel, zircon, and apatite occur in trace amounts. Thus, this is a typical continental terrigenous assemblage. Authigenic barite and siderite occur in several samples. At Site 105 sphalerite is present not within, but just below the variegated sequence.

Volcaniclastic sediments at Sites 382 and 385 are rich in heavy minerals. Hornblende (including common green and reddish brown basaltic varieties), clinopyroxene, and 
sphene are the dominant components of the heavy fraction. Apatite is common, and epidote, spinel, zircon, rutile, anatase, and monazite are present in minor amounts along with authigenic barite and siderite. Magnetite dominates the opaque minerals with minor amounts of iron hydroxides (goethite?). This assemblage cannot be considered as purely volcanogenic (basaltic) because although alkaline-basalt minerals dominate, significant metamorphic minerals are present.

Zeolites - In the Upper Jurassic red marl of Hole 391C zeolites were neither detected by $\mathrm{X}$-ray nor by examination of thin sections. They are also absent in corresponding red limestones at Sites 100 and 105. Abundant clinoptilolite was found in only one of the analyzed Upper Cretaceous variegated sediments (Zemmels et al., 1972).

Zeolites were found in the light coarse fraction of Leg 43 non-volcaniclastic claystones in Holes $382(5 \%), 385$ $(12 \%-20 \%)$, and $386(90 \%$ in $38-5,82-85 \mathrm{~cm})$. X-ray data of Koch and Rothe (in press) show 1 to 3 per cent clinoptilolite in bulk samples from Holes 382 and 385 and from the uppermost portion of the variegated sequence in Hole 386. The lower portion of the interval in Hole 386 (Cores 38-40) contains 6 to 18 per cent clinoptilolite and 0 to 7 per cent of phillipsite. Here zeolite contents seem to correlate with silicification (disordered cristobalite). Both phillipsite and clinoptilolite are present in volcaniclastic sediments at Sites 382 and 385 . Analcite was also found in several samples.

Organic Phosphates - Silt- and fine sand-size phosphatic grains were found in the coarse fraction and thin sections of the variegated and red sediments. The grains are light brown or pale yellow, isotropic, irregular in shape, with smooth contours. They are presumed to be somewhat altered fish bone fragments. The phosphate grains comprise up to 72 per cent of the light coarse fraction in the Hole 382 non-volcaniclastic variegated claystones, 13 to 18 per cent in the corresponding layer of Hole 385,1 and 15 per cent in the lower portion of the variegated interval at Site 386 . We encountered the rare phosphate particles in thin sections of both Cretaceous and Upper Jurassic sediments. These may be interpreted as evidence of a pelagic depositional environment and low accumulation rates.

Iron and Manganese Minerals - The sediments are predominantly red and brown which indicates oxidizing conditions and thus we would expect oxides of iron and manganese to be present. Amorphous iron hydroxides ("limonite"') are probably an important constituent of the Cretaceous variegated sediments, as noted above. Hematite is a minor component in Hole 105, whereas goethite comprises up to 60 per cent of several blebs or layers (Zemmels et al., 1972, table 11). Fe-montmorillonite, groutite (?), siderite, pyrite, and todorokite also occur. Minerals of bivalent iron probably formed in reducing conditions, which exist (or previously existed) in some gray layers which are relatively rich in organic matter.

Authigenic hematite is common in the Upper Jurassic red marls at Sites 100, 105, and 391. It occurs as rare, small, crystals or more abundant finely dispersed flakes. X-ray data show it comprises 2.9 to 3.6 per cent in the less than 2 $\mu \mathrm{m}$ fraction (Zemmels et al., 1972). Neither goethite nor amorphous hydroxides are present, as shown by phase analyses of Hole $391 \mathrm{C}$ samples.
Except for the volcaniclastic sequences of the New England Seamounts, where local basaltic components and products of their alteration predominate, the mineral assemblages of the variegated and red sediments therefore give strong evidence for a continental origin of both clastic (quartz, feldspar, $\mathrm{Qz} / \mathrm{Fe}$ ratio, heavy minerals) and clay (mica, kaolinite) minerals. Authigenic minerals, including barite, rutile, hematite, siderite, sphalerite, goethite, chalcedony, cristobalite, and others, were probably formed by normal diagenetic processes, although some hydrothermal alteration may also have been a factor.

\section{CONCLUSIONS}

Two major sequences of red or variegated sediments occur in the Mesozoic sedimentary section of the western North Atlantic: Upper Jurassic and Upper (partly lower?) Cretaceous. Dominantly red and brown colors indicate that they were deposited in well-oxygenated bottom waters and remained under oxidizing conditions during their early diagenesis. These features contrast with those of the sediments above and below which are mainly gray or black and were thus deposited under reducing conditions. The high state of oxidation of iron and manganese is confirmed by phase analyses and by the presence of characteristic authigenic minerals: iron and manganese hydroxides (limonite, goethite, todorokite) or oxides (hematite). These minerals are the main staining compounds resulting in the sediment colors.

The distinct color change from gray to red and brown seems to correlate with a sharp decrease in sediment accumulation rates and may, therefore, be interpreted as transition from a hemipelagic to a pelagic environment. The red sediments have other characteristics of pelagic sediments, including low organic carbon contents, relatively high iron contents, occasional concentrations of manganese (including nodule-like forms), relatively high contents of several trace elements (partly in conjunction with the occurrence of manganese or manganese nodules $[\mathrm{Ni}, \mathrm{Cu}]$ in the sediments), presence of bone debris, zeolites, and barite. Only pelagic fossils (ammonites, nannofossils) have been found in the Upper Jurassic red marl, and the Upper Cretaceous variegated claystones are virtually barren and thus resemble pelagic red clay. The content of coarse terrigenous matter in both units is very low which also indicates a pelagic environment.

The bulk composition of the sediments, both chemical and mineralogical (on carbonate-free basis), is obviously terrigenous in origin, except that of the New England Seamounts' Upper Cretaceous volcaniclastic sequence. Clear evidence of continental sediment supply, such as high quartz content, high $\mathrm{Qz} / \mathrm{Fe}$ ratio, clay minerals (mica, kaolinite), heavy mineral assemblages, high aluminum content, and $\mathrm{Al} / \mathrm{Ti}$ ratio appear in both rock sequences. Rare, but characteristic quartz sandy and silty interbeds are present in the Upper Cretaceous variegated claystones at Sites 105 and 391. They indicate that either occasional influxes of coarse terrigenous matter occurred or, more likely, winnowing by bottom currents left "residual" concentrations of coarse-grained sediments.

On the basis of geochemical and mineralogical data, we can speculate about the continental source area which 
supplied the Upper Jurassic and Upper Cretaceous basins with terrigenous matter. The kaolinite- and quartz-rich fine-grained, high-aluminum and low-titanium, clay matrix was probably derived from tropical lateritic weathering of granitic rocks. This may also explain the high iron oxides and low manganese content in the sediments. Some intervals of relatively high titanium within the Upper Cretaceous sequence are either produced by submarine volcanic events during sedimentation, or by inclusion of some high-titanium weathering products.

Lancelot et al. (1972) proposed the following explanation for the origin of the Upper Cretaceous variegated (multicolored) sediments drilled at Site 105. Iron and manganese oxides were derived from hydrothermal exhalation associated with volcanic activity in the mid-ocean rift zone. Low accumulation rates of the variegated clays prevented the oxides from being diluted by other sediments even those far from the source area. The occurrence of a Late Cretaceous-early Tertiary volcanic phase in the western North Atlantic was proposed because of the abundant volcanic material in Upper Cretaceous sediments from various parts of the Atlantic Ocean (Legs 1, 2, 14). Proponents of the view emphasize that the interval is characterized by a very low accumulation rate, as a result of very small influx of terrigenous material, and absence of biogenic material. They contend that there were also periods of erosion within the long time interval between Eocene and Early Cretaceous when the variegated clays were deposited.

Lancelot et al. (1972, p. 911) also suggested that active ridge exhalations influenced the Upper Jurassic red limestones at Sites 99, 100, and 105 and were responsible for the high hematite content and red color.

Our data (Murdmaa et al, this volume), as well as the recalculated chemical analyses from Leg 11 (Lancelot et al., 1972), do not provide any significant evidence that these are metalliferous sediments. None of the characteristic ratios ( $\mathrm{Fe} / \mathrm{Al}, \mathrm{Mn} / \mathrm{Al}, \mathrm{Fe} / \mathrm{Ti}, \mathrm{Mn} / \mathrm{Ti}$ ) show sharp constant increase as seen in the mid-oceanic or Red Sea metalliferous sediments (Boström, Peterson, et al., 1969; Boström 1973; Bischoff, 1969; Lisitzyn et al., 1976; Strakhov, 1976). No trace element concentrations were found that require the sediments be metalliferous. On the contrary, we need to explain the low concentrations of $\mathrm{Mn}, \mathrm{Cu}, \mathrm{Ni}, \mathrm{Co}$, and $\mathrm{Zn}$ in most samples as compared with average values for pelagic sediments (Chester, 1965; Strakhov, 1976).

The exhalative origin of the sediments may be assumed only for Site 105 Upper Jurassic red limestones which are directly underlain by basalts. Chemical data, however, are not available for this site. In other cases, especially in the Upper Cretaceous section, the red and variegated sediments are deposited far from any known spreading center. These are separated from basaltic basement by thick sediment layers and do not show any distinct association with younger volcanic centers. The thin, non-volcaniclastic, upper layer on top of the Upper Cretaceous volcaniclastic sequence of the New England Seamounts is quite different both geochemically and mineralogically from underlying sediments. On the other hand, it is similar to variegated sediments of other sites and thus appears to have been deposited independent from any local exhalative source. The wide areal extent of the variegated and red lithofacies in both the western and eastern North Atlantic is also difficult to explain in terms of an exhalative origin.

Therefore, I propose that the Mesozoic variegated and red sediments of the western North Atlantic were deposited in pelagic environments, independent (or nearly independent) of volcanic activity. Sediments were supplied from a continental source and deposited at very slow rates. During the Late Cretaceous, the slow pelagic sedimentation which was well below the CCD was temporarily interrupted by nondeposition or erosion. This resulted in stratigraphic hiatuses and probably produced some of the discrete high-iron and high-manganese layers found in the sequence. Bottom currents probably produced some of the sedimentary structures, such as laminations, cross-laminations, and quartz silt interbeds. Distinct banding of the variegated claystones may have resulted from oscillations in sediment and organic matter supply, with subsequent diagenetic migration of iron and manganese in the contrasting redox conditions.

Drastic changes in geography and environment must have taken place during the transition from hemipelagic (or turbiditic) to pelagic sedimentation. Changes may have included decrease in supply of terrigenous sediments owing to marine transgressions onto adjacent coastal plains, lowering of continental relief, change from humid to arid conditions, and activization of bottom currents. The latter was probably important during the Late Cretaceous and resulted from further opening of the Atlantic. However, intervals of variegated sediments with decrease in accumulation rates and corresponding marked changes in geochemistry are not quite simultaneous at different sites. Distinct variegated sediments occur in the Albian-Aptian carbonate sediments (Site 390) and in the Albian to Cenomanian black claystone sequence of Site 391. These sediments are probably influenced by local events. Nevertheless, these local events are also related to hiatuses and sharp changes in sedimentation environment. Thus the variegated calcareous oozes were deposited first on top of the shallow-water limestones on the $J$-anomaly Ridge (Site 384) in Coniacian-Santonian time, and on the Blake Nose during the Albian-Aptian (Site 390). In most cases, the variegated sediments mark cessation of the black carbon-rich clay accumulation, which was not simultaneous at the different sites.

\section{REFERENCES}

Bischoff, J.L., 1969. Red Sea geothermal brine deposits - their mineralogy, chemistry and genesis. In Hot brines and recent heavy metal deposits in the Red Sea: Degens, E.T. and Ross, D.A. (Eds.), New York (Springer Verlag, Inc.), p. 368.

Boström, K., 1973. The origin and fate of ferromanganoan active ridge sediments: Stockholm Contrib. Geol., v. 27, p. 149243.

Boström, K., Peterson, M.N.A., Joensuu, O., and Fisher, D.E., 1969. Aluminum poor ferromanganoan sediments on active oceanic ridges: J. Geophys. Res. v. 74, p. 3261.

Chester, R., 1965. Elemental geochemistry of marine sediments. In Treatise on chemical oceanography: v. 2, New York.

Hayes, D.E., Pimm, A.C., et al., 1972. Initial Reports of the Deep Sea Drilling Project, Volume 14: Washington (U.S. Government Printing Office).

Hollister, C.D., Ewing, J.I., et al., 1972. Initial Reports of the Deep Sea Drilling Project, Volume 11: Washington (U.S. Government Printing Office). 
Koch, R. and Rothe, P., in press. X-ray mineralogy studies - Leg 43. In Tucholke, B., Vogt, P., et al., Initial Reports of the Deep Sea Drilling Project, Volume 43: Washington (U.S. Government Printing Office).

Lancelot, Y., Hathaway, I.C., and Hollister, C.D., 1972. Lithology of sediments from the Western North Atlantic Leg 11. In Hollister, C.D., Ewing, J.I., et al., Initial Reports of the Deep Sea Drilling Project, Volume 11: Washington (U.S. Government Printing Office), p. 901-949.

Lancelot, Y. Seibold, E., et al., 1977. Initial Reports of the Deep Sea Drilling Project, Volume 41: Washington (U.S. Government Printing Office).

Lisitzyn, A.P., Bogdanov, Y.A., Murdmaa, I.O., Serova, V.V., Zverinskaya, I.B., Lebedev, A.I., Lukashin, V.N., and Gordeev, V.V., 1976. Metalliferous sediments and their origin. In Geographical-Geophysical Researches in the South-Eastern part of the Pacific Ocean; Oceanological Res. No. 29: Moscow (Publ. House "Nauka") (in Russian), p. 289-379.
Murdmaa, I.O., in press. Coarse fraction mineralogy of the Leg 43 sediments. In Tucholke, B., Vogt, P.R., et al., Initial Reports of the Deep Sea Drilling Project, Volume 43: Washington (U.S. Government Printing Office).

Murdmaa, I.O., Gordeev, V.V., Bazilevskaya, E.S., and Emelyanov, E.M., in press. Inorganic geochemistry of the Leg 43 sediments. In Tucholke, B., Vogt, P.R., et al., Initial Reports of the Deep Sea Drilling Project, Volume 43: Washington (U.S. Government Printing Office).

Strakhov, N.M., 1976. Problems of geochemistry of recent oceanic lithogenesis: USSR Acad. Sci. Geol. Inst. Trans., v. 292, Moscow (Publ. House "Nauka"), p. 1-299.

Tucholke, B.E., Vogt, P.R., et al., in press. Initial Reports of the Deep Sea Drilling Project, Volume 43: Washington (U.S. Government Printing Office).

Zemmels, I., Cook, H.E., and Hathaway, J.C. 1972. X-ray mineralogy studies - Leg 11. In Hollister, C.D., Ewing, J.I., et al., Initial Reports of the Deep Sea Drilling Project, Volume 11: Washington (U.S. Government Printing Office), p. 729789. 